\title{
Inbreeding in a natural population of the grasshopper Chorthippus nevadensis
}

\author{
J. Cabrero and \\ J. P. M. Camacho
}

Departamento de Genética, Facultad de Ciencias, Universidad de Granada, 18071 Granada, Spain.

Using supernumerary segments as chromosome markers, a high rate of inbreeding has been detected in a natural population of Chorthippus nevadensis. This could be related with the low mobility of these brachypterous grasshoppers.

\section{INTRODUCTION}

The most evident form of polymorphism in grasshopper populations is that caused by the presence of supernumerary chromosome segments, since they have been detected in most the species exhaustively studied cytologically. The great majority of supernumerary segments are heterochromatic, as indicated by their positive heteropycnosis in first meiocytes. However, they show four different types of response to C-banding, which demonstrates the heterogeneity of the heterochromatin they contain (Camacho et al., 1984). In the present report we analyse cytologically a population sample of Chorthippus nevadensis for the presence of supernumerary segments in three chromosome pairs. This demonstrates the existence of inbreeding in this population.

\section{MATERIALS AND METHODS}

Chorthippus nevadensis is a brachypterous grasshopper recently described by Pascual (1978a) which is endemic in the Sierra Nevada (Granada, Spain) at altitudes ranging from $1900 \mathrm{~m}$ to $3300 \mathrm{~m}$ (Pascual, 1978b). During the summers of 1981, 1982 and 1983 six, nine and 71 adult males, respectively, were collected at Alto del Chorrillo $(2700 \mathrm{~m})$ within an area of about $900 \mathrm{~m}^{2}$. The cytological techniques used were those described in Camacho et al. (1984).

\section{RESULTS AND DISCUSSION}

Three chromosome pairs carrying supernumerary segments have been observed in the sample. These segments were small C-bands interstitially located in the $\mathrm{L}_{2}$ and $\mathrm{M}_{6}$ chromosomes besides a larger extra segment darkly C-banded and distally located in the $\mathrm{S}_{8}$ chromosome (fig. 1). Table 1 summarises the frequencies of the different karyomorphs and chromosome types found.

The population sample obtained in 1983 was numerous enough to test the Hardy-Weinberg equilibrium for the $\mathrm{L}_{2}$ and $\mathrm{M}_{6}$ chromosomes. This population sample differed significantly from the equilibrium situation for both the $L_{2}$ and the $M_{6}$ chromosomes: $G=17 \cdot 90, P=2 \cdot 5 \times 10^{-5}$ for the $\mathrm{L}_{2}$ and $G=9.84, P=1.9 \times 10^{-3}$ for the $\mathrm{M}_{6}$. The $G$ statistic, although is more accurate than $X^{2}$ test, gives an order of magnitude error in the probability level since the expected proportion of rare homozygotes is only $0 \cdot 43$. A better approach is to calculate the exact probability of finding $n$ or more of the rare homozygotes, using the binomial distribution. Thus the chance of seeing four or more $\mathrm{L}_{2}$-segmented homokaryotypes was $P=9 \cdot 2 \times 10^{-4}$ and that of seeing three or more $\mathbf{M}_{6}$-segmented homokaryotypes was $P=9 \cdot 1 \times 10^{-3}$. Thus, in both cases there was a significant deficiency of heterozygous karyomorphs, paralleled by an excess of both homozygotes, which denotes the existence of inbreeding in this population. An estimation of the coefficient of inbreeding starting from the deficiency of heterozygotes resulted in the 


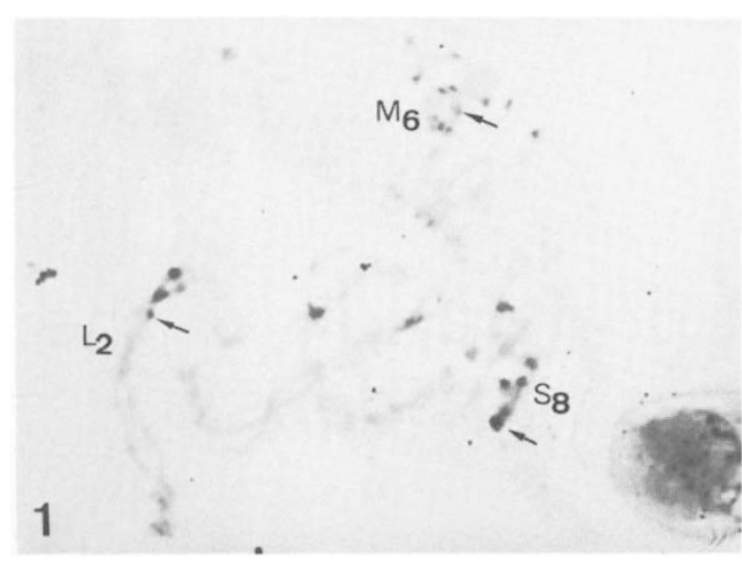

Figure 1 Supernumerary segments (arrows) in Chorthippus nevadensis. Early diplotene cell showing heterozygosity for the $L_{2}, M_{6}$ and $S_{8}$ hivalents.

Table 1 Supernumerary segments in Chorthippus nevadensis. $B$-basic, $S=$ segmented chromosome. $q_{5}=$ frequency of segmented chromosome

\begin{tabular}{|c|c|c|c|}
\hline Chromosome & $\begin{array}{l}\text { Year of } \\
\text { sampling }\end{array}$ & $\begin{array}{l}\text { Karyomorphic } \\
\text { frequencies }\end{array}$ & $q_{s}$ \\
\hline \multirow[t]{3}{*}{$\mathrm{L}_{2}$} & 1981 & $3 B B: 3 B S$ & \\
\hline & 1982 & $6 B B: 2 B S: 1 S S$ & \\
\hline & 1983 & $64 B B: 3 B S: 4 S S$ & 0.0775 \\
\hline \multirow{2}{*}{$\mathbf{M}_{6}$} & 1982 & $8 B B: 1 B S$ & \\
\hline & 1983 & $63 B B: 5 B S: 3 S S$ & 0.0775 \\
\hline $\mathrm{S}_{8}$ & 1982 & $7 B B: 2 B S$ & \\
\hline
\end{tabular}

following values: $F=0.7$ for the $L_{2}$ and $F=0.5$ for the $\mathrm{M}_{6}$. The existence of inbreeding in this species could be favoured by the low mobility of the adult individuals, which show a substantial reduction of their wings. This fact could also be responsible for the inbreeding detected in other species, such as the British and French populations of Chorthippus parallelus (John and Hewitt, 1966; Hewitt and John, 1968; Westerman, 1969, 1970), although we have observed that Spanish populations of this species show frequencies for the extra segments in the $M_{7}$ and $S_{8}$ chromosomes which do not differ significantly from those expected in the HardyWeinberg equilibrium (Cabrero, 1985).

There are two other brachypterous species of Orthoptera in which the observed frequencies for the karyomorphs of extra segments disagree with those expected in the equilibrium, indicating the possible existence of inbreeding. First, some populations of Metrioptera brachyptera show a sig- nificant excess of homokaryotypes for the supernumerary segments in the $\mathrm{L}_{4}$ chromosome (Southern, 1970). Secondly, in Baetica ustulata the frequencies of the ten different karyomorphs for the $\mathrm{M}_{5}$ chromosome (which is polymorphic for the presence of supernumerary segments) differ significantly from those expected under the HardyWeinberg equilibrium (Fernández-Piqueras et al., 1984). The data of these authors would seem to demonstrate the existence of inbreeding in this species, given the significant excess in the frequency of the four homokaryotypes and deficiency in the frequency of the six heterokaryotypes (see their table 3). However, this inference may not be sound because the karyomorphic frequencies were calculated after pooling individuals collected during three different years from three different altitudes in the Sierra Nevada (Granada, Spain): these results could be a consequence of the Wahlund's principle.

\section{REFERENCES}

CABRERO, J., 1985. Estudios citogenéticos en saltamontes de la subfamilia Gomphocerinae: Heterocromatina, reordenaciones cromosómicas y actividad nucleolar. Tesis doctoral, Universidad de Granada.

CAMACHO, J. P. M., VISERAS, E., NAVAS, J. AND CABRERO, J., 1984. C-heterochromatin content of supernumerary chromosome segments of grasshoppers: detection of an euchromatic extra segment. Heredity, 53, 167-175.

FFR NANDEZ-PIQUERAS, I., ROURIGUEZ CAMPOS, A., SENTIS CASTAÑo, C. AND ROJO GARCIA, E., 1984. C-heterochromatin variation in the monospecific genus Baetica (Orthoptera: Acrididae). Caryologia, 37, 69-76.

HEWITT, G. M. AND JOHN, B., 1968. Parallel Polymorphism for Supernumerary Segments in Chorthippus parallelus (Zetterstedt) I. British populations. Chromosoma, 25, 319-342.

JOIN, B. AND HEWITT, G. M., 1966. A polymorphism for heterochromatic supernumerary segments in Chorthippus parallelus. Chromosoma, 18, 254-271.

PASCuAl, F., 1978a. Descripción de una nueva especie de Chorthippus Fieber, 1852, de Sierra Nevada, España. EOS Revista Española de Entomologia, Tomo LIl (1976), 167 173.

PASCUAI, F., 1978b. Estudio preliminar de los Ortópteros de Sierra Nevada, I: Introducción general e inventario de especics. Bol. Asoc. esp. Entom, I (1977), 163-175.

SOUTHERN, D. I., 1970. Polymorphism involving heterochromatic segments in Metrioptera brachyptera. Chromosoma, 30, 154-168.

WESTERMAN, M., 1969. Parallel polymorphism for supernumerary segments in Chorthippus parallelus (Zetterstedt) II French populations. Chromosoma, 26, 7--21.

Westerman, M., 1970. Parallel polymorphism for supernumerary segments in Chorthippus parallelus V. A new polymorphism in Europe. Heredity, 25, 662-667. 